\title{
INDOCTRINATING MUSLIM YOUTHS: Seeking Certainty Through An-Nabhanism
}

\section{Syamsul Rijal}

State Institute for Islamic Studies (IAIN) Antasari Banjarmasin, Indonesia

\section{Abstract}

This article discusses the Hiqut Tahrir Indonesia's (HTI) mechanism and medium of indoctrination as well as their impact on young Muslims' mind and behaviour. It argues that intensive halqa in HTI plays a crucial role in implanting An-Nabhani's doctrines into prospective members as well as senior ones so that they can maintain their ideological uniformity and dedication to HTI. In such a traditional medium of teaching, members are not encouraged to use critical thinking but to adopt and implement the HT doctrines correctly as guided by one supervisor (mushrif/mushrifa). Furthermore, the article argues that Muslim youth, especially disaffected ones, are more vulnerable to join HTI since they are at the stage of seeking personal empowerment and identity, social bonds, and channels to express their discontent with life. It is the intersection of these aspects that make young educated people become re-born Muslims who find a 'total' Islamic identity and certainty in HTI.

[Artikel ini membahas mekanisme dan medium indoktrinasiyang dilakukan Hižbut Tabrir Indonesia (HTI) serta implikasinya terhadap cara pandang dan perilaku kalangan muda Muslim. Kegiatan ḥalqa yang dilaksanakan berperan besar dalam menanamkan doktrin-doktrin An-Nabhani, baik terhadap calon anggota maupun kalangan senior. Halqa merupakan cara efektif untuk mempertahankan keseragaman ideologi di kalangan mereka dan menumbubkan kesetiaan terhadap HTI. Dalam ḥalqa, peserta sama sekali tidak didorong -untuk tidak menyebut dilarang-berpikir kritis, melainkan dibuat agar mau mengadopsi dan menerapkan doktrin Hizbut Tabrir (HT) 
seperti diajarkan mushriff/mushrifa. Ditengarai bahwa kalangan muda Muslim, utamanya yang sedang dalam masa labil, lebih berpotensi untuk direkrut bergabung dalam HTI. Hal itu karena mereka sedang dalam masa trasisi guna memenukan identitas dan ikatan-ikatan sosial serta cara/ metode dalam mengekspresikan kekecewaan mereka terhadap persoalan-persoalan duniawi. Pertemuan semua kegalauan tersebut pada gilirannya menjadikan kalangan terdidik. muda Muslim menjadi 'terlahir kembali', mereka merasa menemukan identitas 'Islam-kaffah' dan kepastian dalam HTI.]

Keywords: Hiæ̌biyyin, indoctrination, ḥalqa, commitment, identity

\section{A. Introduction}

In Indonesian today, it is no longer an unusual scene to see long lines of individual HTI members (usually referred to as hizbiyyin) marching in public along major roads, demanding the restoration of the caliphate and denouncing world capitalism and western democracy. Walking several kilometers at a time, HTI activists enthusiastically raise and swing the distinctive black and white flags (liwa' and raya) of Hizbut Tahrir (HT) while shouting 'Allahu Akbar' ('God is Most Great'). While some activists hold the banners, others are busy distributing leaflets and stickers to people at the side of the roads. Revolutionary Islamic jargon colours the HTI rhetoric. The bizbiyyin seem sincere and dedicated in carrying out their da wa aimed at awakening the umma. Moreover, they appear confident and eloquent when talking about the crisis of capitalism and the urgent need to adopt Islam as the solution. The scene raises the question for us of why these young Muslims are so critical of Western concepts and so enthusiastic in joining rallies and demonstrations. Indeed, what makes bizbiyyin become so committed and dedicated to the HTI movement?

The discussion of commitment and dedication to a radical movement cannot be isolated from an examination of the indoctrination process which enables members to grasp and internalise its ideology and tenets. To date, there has been no study of indoctrination by scholars of transnational Islamist movements, especially of those in Indonesia. Drawing on field research on several rank-file members of HTI in Makassar, South Sulawesi, this article seeks to fill this gap. The HTI movement provides an interesting case in which members show strong 
influences of indoctrination in their thought and behaviour. In this article I argue that intensive indoctrination in HTI is crucial in shaping the thinking of bizbiyyin and serves to maintain ideological uniformity and commitment to the movement.

The term 'indoctrination' sounds pejorative to many, as it tends to be associated with terms such as brainwashing, deprogramming, mind manipulation and mind control through coercion. The negative associations of the term are due to the development of the democratic notion in education which regards indoctrination as a coercive educational method of totalitarian regimes. ${ }^{1}$ In this article, however, I use indoctrination as a neutral concept which refers to a classical method of teaching. To follow the definition by William Heard Kilpatrick, indoctrination refers to "the implanting of doctrines which are to be held uncritically." The doctrines in this regard are commonly related to political, moral and religious beliefs. ${ }^{3}$ As I will show, indoctrination in HTI does not involve coercion, yet it guides people to understand and internalise Islam under the closed system of interpretation of its founder, Taqiyuddin An-Nabhani. The indoctrination process in HTI is conducted through intensive halqa (study circle) and socialisation which aim to maintain ideological cohesion among the members. While recruitment serves to attract people to join, indoctrination is essential to produce dedicated bizbiyyin. Through intensive halqa, young Muslims can find certainty and a new identity, as well as maintaining their dedication to the movement.

The first part of this article deals with the emergence and development of HTI in South Sulawesi. The second part analyses the process and method of indoctrination through balqa in HTI. The third part deals with young members of HTI and their susceptibility to HT ideology and doctrines. The last part analyses the commonly repeated narratives of bizbiyyin and their relation to the effects of indoctrination.

${ }^{1}$ A. Snook, Indoctrination and Education (London and Boston: Routledge \& Kegan Paul, 1972), p. 17.

${ }^{2}$ Snook (ed.), Concepts of Indoctrination: Philosophical Essays (London and Boston: Routledge \& Kegan Paul, 1972), p. 4.

${ }^{3}$ Richard H. Gatchel, "The Evolution of the Concept" in Snook (ed.), Concepts of Indoctrination, p. 19. 


\section{B. Glimpse of HTI in South Sulawesi}

The emergence of HTI in South Sulawesi cannot be isolated from the role of the Lembaga Dakwah Kampus/LDK (Campus Preaching Organisation) network during the 1990s. Makassar, the capital city of South Sulawesi, has long been the destination of study for people in Eastern Indonesia, as it provides a range of universities such as Universitas Hasanuddin (UNHAS), Universitas Negeri Makassar (UNM), Universitas Islam Negeri Alauddin (UIN), Universitas Muslim Indonesia (UMI) and Universitas 45, to mention a few. University campuses provide the base for Islamic movements developed through LDK. In Makassar, UMI and UNHAS campuses established LDK in the early 1990s within LDK's network, a move initiated by LDK activists in West Java. However, in its earliest phase of development LDK was a loose institution which accommodated students from any stream of Islamic organisations. According to Hasanuddin Rasyid, it was the LDK activists of UMI campus who played a key role in bringing HTI ideas and developing HTI in Makassar. ${ }^{4}$ This was due to intensive interaction between LDK activists in UMI and those in Java, and Rasyid recalls that in the early 1990s he and his friends from UMI's LDK joined the Lembaga Tahfidzul Qur'an (Organisation for Qur'anic Memorisation), a campus Islamisation program initiated by the rector of UMI, Abdurrahman Basalamah. As a part of the program, the students received information from the LDK of Insitut Keguruan dan Ilmu Pendidikan/IKIP (Institute for Teaching Learning and Education) in Malang, East Java that a month-long course in Arabic language was being offered. Interested in studying Islam and Arabic, 15 LDK activists, including Rasyid went to Malang to attend the course, during which they were introduced to the ideas of various Islamic movements, including those of Hizbut Tahrir. ${ }^{5}$ When returning to Makassar, they founded a forum on Islam in 1995, due to their interest in HT thought. They developed the discussion of HT ideas, such as Islamic faith (akidah Islam), principles of shari'a, world ideologies, the system of government in Islam, Islamic economy, and so forth. ${ }^{6}$ This was the

${ }^{4}$ Hasanuddin Rasyid, Interview, 13 December 2008.

${ }^{5}$ Ibid.

${ }^{6}$ Badruzzaman, “Gerakan Keagamaan 'Hizbut Tahrir' dan Lektur Rujukannya”, http:/ /bz69elzam.blogspot.com/2008/07/gerakan-keagamaan-hisbut-tahrir-dan.html, accessed 1 April 2009. 
embryo for the emergence of HTI in Makassar and South Sulawesi. At first, HTI activists restricted participation in their discussion groups to students on the campuses. Then, realising that HT's struggle is concerned with the establishment of an Islamic society and an Islamic state, the LDK activists began to propagate HT ideas outside the campuses. As noted by Badruzzaman, there were three pioneer activists in the establishment of the HTI branch in Makassar; they were Hijrah Dahlan, Alimuddin, and Hasanuddin Rasyid. ${ }^{7}$

The launching of a branch of HTI in Makassar was initiated through a seminar on the caliphate held at UNHAS in 2000. This followed the emergence of HTI into the public eye with its International Caliphate Conference in May 2000 in Senayan Stadium, Jakarta. ${ }^{8}$ The HTI seminar in Makassar was attended by around 1,000 people, including students and various segments of society. ${ }^{9}$ The speakers in the seminar were the Abdurrahman Basalamah (Rector of UMI), Mattulada (an historian at UNHAS) and Utsman (HTI activist from Surabaya). ${ }^{10}$ Since then, HTI has operated in public in Makassar, organising various activities in order to disseminate its ideas and attract public support.

As I have already established, from its emergence in Indonesia up to the present, HTI's base of recruitment and education has been the university campuses, especially through the LDK and study clubs. As I observed on fieldwork in Makassar, each university campus has a branch, or what recently have been called 'HTI chapters'. There are pamphlets displayed on campus information boards under the name of each HTI chapter or its study clubs. It seems that HTI activists have dominated LDK campus activities in Makassar and therefore, as one HTI activist said, LDK tends to be synonymous with HTI in her campus (UMI). ${ }^{11}$ Moreover, there is a network of LDK branches the-so-called Badan Koordinasi Lembaga Dakwah Kampus/BKLDK (the LDK Coordinating Board), which is dominated by HTI activists. LDK and the study clubs run

${ }^{7}$ This activist now has become the spokesperson (Humas) of DPD 1 HTI in South Sulawesi.

${ }^{8}$ Hasanuddin Rasyid, Interview, 13 December 2008.

${ }^{9}$ Badruzzaman, “Gerakan Keagamaan 'Hizbut Tahrir' dan Lektur Rujukannya”, n.d.

${ }^{10}$ Hasanuddin Rasyid, Interview, 13 December 2008.

${ }^{11}$ Rahmawati, Interview, 9 January 2009. 
by HTI usually host seminars and discussions of current issues as the first step in attracting students to join them. From there, the participants will be introduced to HT ideas and later be directed to become HTI members through set stages of education. Gerakan Mahasiswa Pembebasan/ Gema Pembebasan (the Student Liberation Movement) is an HTI expansionist wing in the university campuses, dealing with political issues preferred by students. However, as several activists said, since late 2008 Gema Pembebasan has been dissolved into an HTI chapter following a stipulation from DPP HTI in Jakarta, the board of the HTI chapter taking responsibility for expanding da'wa on campus.

Besides LDK and the HTI chapter, Islamic study clubs also play an important role in recruitment. Each campus has its own name for such study clubs. The study club on the UNM campus, for instance, is called Forum Studi Islam Kontemporer 'al-Umdah'/Fosdik 'al-Umdah '(Contemporary Islamic Study Forum of Basic Issues), while at UMI campus it is called Forum Studi Islam Ideologis/FOSIDI (Islamic Ideological Study Forum). The activities of the forums comprise conducting discussions and seminars on contemporary politics and Islamic issues and producing bulletins and pamphlets which disseminate HT ideas to the students. Those who join the discussions in these forums and show interest in the issues canvassed will be targeted to participate in HTI training and further ḩalqa.

As a branch of HTI, South Sulawesi has committees at the provincial level called Dewan Pimpinan Daerah I/DPD I (Provincial Executive Committee), the district level under the Dewan Pimpinan Daerah II/DPD II (Provincial Executive Committee), and at the subdistrict level called the Dewan Pimpinan Cabang/DPC (Executive Committee for Sub-district). The structure of DPD I consists of the head, spokesperson, and five departments which include: Lajnah Tsaqafiyyah (Department of Culture), Lajnah Siyasiyyah (Department of Politics), Lajnah Maslabiyyah (Department of Welfare), Lajnah Fa'aliyyah (Department of Administration) and Lajnah I'lamiyyah (Department of Information). ${ }^{12}$ The head of DPD I is Sabran, while the spokesperson (Public Relation, HUMAS DPD I) is Hasanuddin Rasyid. The latter's

${ }^{12}$ See Sukma, Hiqbut Tahrir Daerah Sulawesi Selatan, Skripsi (Honour thesis) at the Faculty of Social and Political Science (Makassar: University of Hasanuddin, 2008). 
position is more dominant in representing HTI in public and media coverage in comparison to the head, a rule that applies to HT at the state and international levels as well. It is difficult for researchers to interview the head of DPD I and the chair of each department because the only channel for getting information is through the spokesperson, either at DPD I or DPD II. Rasyid stated that HTI has district level DPD II's in almost all districts in South Sulawesi except for the Christian based districts such as Tana Toraja and Toraja Utara. ${ }^{13}$ It appears that HTI in South Sulawesi has gradually expanded its foothold from the capital city Makassar to outlying districts and villages. Despite the growing membership of HTI in South Sulawesi, the number of its members is still a tiny compared to the Muslim majority in the region. Based on my observation of a large rally conducted in Makassar, its size is around 5,000 to 10,000 actual members.

Besides running intensive education programs for members, activists of HTI in South Sulawesi have orchestrated various activities in order to win the support of society at large. Their formal activities range from peaceful demonstrations or rallies on the street to intellectual activities, such as hosting seminars, discussions and workshops. Buletin alIslam (Islamic Bulletin), which is distributed by HTI activists every Friday at many mosques throughout South Sulawesi, especially in Makassar, is the most important media outlet propagating their da'wa in broad terms. The last page of the bulletin often contains information of HTI's coming activities, which openly invite people to attend. HTI of South Sulawesi has even organised public prayers for two important days of religious commemoration (Idul Fitri and Idul Adha), providing one of their members as the khatib or preacher. They also cooperate with several local radio broadcasts in Makassar such as al-Ikhwan, Barata, Merkurius, Smart FM, and Suara Celebes to deliver Islamic sermons. ${ }^{14}$ Moreover, many of the HTI student activists write their opinions and publish them in the local newspapers.

${ }^{13}$ Hasanuddin Rasyid, Interview, 13 December 2008. When organizing a big rally in Makassar, DPD I HTI always puts in contact persons for its members in several districts through pamphlets and billboards. I once found 14 of 20 districts have local contacts in pamphlets.

${ }^{14}$ Hasanuddin Rasyid, Interview, 6 January 2009. 


\section{Indoctrinating An-Nabhanism Through Halqa}

In various printed works of Hizbut Tahrir, it is always emphasised that Islam is the ideology of the party and superior to all other ideologies. Islam, in HT's perspective, however, refers to the interpretations of Islam provided by its founder, Taqiyuddin An-Nabhani. Due to this strict adherence to An-Nabhani's thoughts, I call HT's ideology 'AnNabhanism.' Conceiving of itself as a political party, HT intends that individuals embrace the ideological platform of the party and carry out its programs. One of HT's methods in guarding ideological uniformity among the bizbiyyin is the process of adopting canonical ideas (tabanni). ${ }^{15}$ HT has both an 'adopted canon' (thaqafa al-mutabanna) and an 'un-adopted canon' (thaqafa ghayr-l-mutabanna). ${ }^{16}$ According to Taji-Farouki, the former canon consists of texts addressed to the party and its members in order to direct their conduct, while the latter canon is addressed both to HT and Muslims in general. It is obligatory for each member to embrace the former and deviation from it could lead to disciplinary measures. ${ }^{17}$ Both canons contain selected ideas, opinions and laws related to various aspects which are believed to be wholly derived from Islam. The works include Niz̧ăm al-Islām (The System of Islam), Niz̧ām al-Hukm fi-l-Islām (The Ruling System of Islam), Nižàm al-Iqtisad fi-l-Islam (The Economic System of Islam), Nižàm al-Ijtimä' fi-l-Isläm (The Social System of Islam), al-Takattul al-Hizbiy (The Party Structure), Mafäbim Hiøbut Tabrir (The Concepts of Hizbut Tahrir), al-Dawla al-Islamiyya (The Islamic State), Shakhsiyya al-Islamiyya (The Islamic Personality), in 3 volumes, Mafähim Siyasiya li Hizbit Tabrir (The Political Concepts of HT), Nazarat Siyasiyya li Hizbit Tabrir (The Political Views of Hizbut Tahrir), Muqaddima al-Dus tür (Introduction to the Constitution), al-Khiläfa (The Caliphate), Kaifa Hudimat al-Khiläfa (How the Caliphate was Destroyed), Nižàm al- Uqüba (The Penal Code), Aḅkām al-Bayyina (The Rules of Evidence), Naqd alIshtiräkiya al-Marksiyya (Refutation of Marxist Communism), al-Tafkir (Thought), Sur'atu-l-Badǐab (Presence of Mind), al-Fiker al-Islämiy (Islamic Thought), Naqd al-Naz̧ariya al-Iltizām fi-l-Qawānin al-Gharbiyya (Refutation

${ }^{15}$ Suha Taji-Farouki, A Fundamental Quest: Hiab al-Tabrir and the Search for the Islamic Caliphate (London: Grey Seal, 1996), p. 135.

${ }^{16}$ Ibid.

${ }^{17}$ Hizbut Tahrir Indonesia, Mengenal Hizbut Tabrir: Partai Politik Islam Ideologis (Pustaka Thariqul Izzah, 2000), pp. 12-13. 
of the Theory of Liability in Western Law), Nida'-l-Har (A Warm Call), Siyasa al-Iqtisádiyya al-Muthlā (The Ideal Economic Policy), and Amwäl fi-l-Dawla al-Kbiläfa (The Treasury in the Caliphal State). ${ }^{18}$

HTI literature does not specifically divide the books according to each canon. However, some members cited examples of the 'adopted

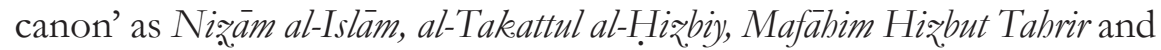
al-Dawla al-Islamiyya, while the 'unadopted canon' included Nižăm al-Iqtisad fi-l-Isläm, al-Fiker al-Islämiy and Nizām al-Uqüba. The books appear as curriculum for new recruits (däris), and biabiyyin proper and each member, whether junior or senior, is required to join a weekly halqa in order to study the listed works. Absence from the halqa meeting without good reason could lead to dismissal from HTI.

\section{Halqa and the Indoctrination Process}

The halqa plays the most important role as the medium of indoctrination in HT. Farouki desribes it as "a small unit of party members and new recruits formed for the intensive study of the party ideology under the supervision of an experienced member." ${ }^{\prime 19}$ Meetings consist of five individuals gathering around a supervisor and usually last for two hours per session. Membership to HT is conditional upon the candidate's participation in intensive halqa. HTI members call this education through halqa the 'culturing process' (tatgif) to distinguish it from that of schools and universities. This is because the halqa regimen for HTI aims not only to educate members but also to develop what they have learned into their everyday behaviour. In this regard, halqa serves to inculcate HT ideology to the new recruits and members both in mind and in their everyday behaviour. The HT supervisor, mushrif (m.) or mushrifa (f.) has the important duty of maintaining the members' understanding in accordance with the approved HT interpretations. Instead of encouraging critical thinking among members the supervisor, acting as the mouthpiece of An-Nabhanism, directs them to follow his or her perspectives.

The indoctrination process of halqa uses the traditional method of Islamic learning in which the teacher holds the authority to transfer

${ }^{18}$ Hizbut Tahrir Indonesia, Mengenal Hiz̧ut Tahrir, p. 27-29.

19 Taji-Farouki, A Fundamental Quest, p. 125. 
knowledge to his or her students without encouraging criticism or debate. The process of learning begins with each member having to read out a passage of the book under study. The supervisor then invites members to raise questions related to the passage and its relevance to contemporary developments, and later he or she will answer them. For female activists, the process of completing a book takes more time than for fellow male activists, as they use the Arabic version while the latter use Indonesian translations. In the process, each member has to read out the Arabic passage and translate it into Indonesian before moving on into the question and answer session. ${ }^{20}$ As a comparison, the male group may take one year to complete studying the book Nižam al-Islam, while the female group may take two years. ${ }^{21}$ At each ḥalqa meeting, HTI members usually study two or three paragraphs of set text, depending on the capability of the members to comprehend them.

The supervisors are responsible for the indoctrination and behavioural development of their members. They are full bizbiyyin who regard this supervision as an obligation for developing da'wa. Indeed, as HT requires, each full member will be assigned to become a supervisor. Their task is not only related to halqa supervision, but they also help members to enhance their basic knowledge of Islam and religious practices (ibada) such as prayer, fasting and reciting the Qur'an correctly. They also monitor the daily behaviour of members away from the halqa cells. In this way, they become religious mentors for those members who might have problems within their personal lives. Self-awareness and self-discipline are implanted, especially in the new recruits; for example, any who come more than 15 minutes late after the halqa begins will not be allowed to join the session. ${ }^{22}$ Thus the presence of the supervisors is crucial in directing, implanting and maintaining the ideological, political and religious beliefs of HT in new recruits and members alike.

Apart from running the intensive halqa, supervisors also suggest additional learning for their members which they call 'individual learning' (Dirasah Fardiyyah/DF) and 'additional insight' (Tsaqafah Tambahan). ${ }^{23}$ This

${ }^{20}$ Information gained from interviews with several HTI members in Makassar.

${ }^{21}$ Interview with Hernawati, Makassar, 29 December 2008.

${ }^{22}$ Interview with Maryam, Makassar, 9 January 2009.

${ }^{23}$ It seems that this additional learning process is applied only to female bizbiyyin as I did not gain any information related to this from male biz̧biyyin. 
is aimed at broadening the ideological comprehension of the members and training them to analyse social and political events based on the HT perspectives which they have acquired. In relation to individual learning, the supervisors ask their cell members to read at home a particular book or item of information from the media on some actual issue. In response to the global financial crisis, for instance, members were encouraged to read an Islamic economic text under the guidance of their supervisor. The following week, they meet their supervisor to present the results of their reading. On such occasions, the supervisor also uses the session to test members' understanding of HT ideology as gained from intensive halqa, as well to check their political insight (Wawasan Politik/Waspol). ${ }^{24}$

As part of ideological indoctrination, the supervisor will guide the members to produce answers and analyses in accordance with HT ideology. This presentation and examination meeting is called the 'weekly following activity' (Mutataba'at Usbu'iyah/MU). On the other hand, 'additional culture' sessions are held at special times, differing from halqa and MU. The texts chosen for study are taken from the 'unadopted canon', which are not used in the intensive halqa. According to HTI female members, the first book used is entitled Min Muqawwima al-Nafsiya alIslamiyya (Pillars of the Islamic Personality), anonymous author, published under HTI imprimatur. It contains a range of Qur'anic verses and Hadith (prophet's sayings) under various themes of Islamic personality building. It is interesting to note that female hizbiyyin customarily use familiar abbreviations to refer to their activities and books, such as MU (Mutataba'at Usbu'iyah), DF (Dirasab Fardiyab), Waspol (Wawasan Politik) and MM (Min Muqawnimat). Given all these various learning activities, the bizbiyyin are kept busy, attending three sessions a week, which include balqa, MU and Thaqafah Tambahan.

\section{Texts as a Basis for Indoctrination}

As we have seen, initial indoctrination through intensive b̧alqa seems essential to mould the minds of the new recruits, the daris and to familiarise introductory HT doctrines. Halqa, in the first place, may attract them to keep participating and eventually lead them on to become actual members. Most of the bizbiyyin I met deny that they have been

\footnotetext{
${ }^{24}$ Interview with Mujahidah and Farah, Makassar, 23 December 2009.
} 
indoctrinated, arguing that membership to HTI is contingent upon the choice of the individual. They emphasise that their decision to participate in HTI is due to a 'process of thinking' (proses berfikir). These members apparently do not realise that they have been indoctrinated through the weekly halqa. In fact, the adoption of HT ideology through 'the process of thinking', as they stress, is part of an indoctrination because of the material they receive in the halqa, which will usually begin by covering Niz̧àm al-Islām for new members.

While there have been various explanations of the differences between indoctrination and instruction, scholars of education suggest that indoctrination can be distinguished from instruction in terms of intention, method and content. ${ }^{25}$ According to John Wilson, indoctrination is being carried out when it is intended that the student arrive at a certain belief. ${ }^{26}$ In the case of HT, indoctrination is to be identified, at least judging from the intention of halqa to implant ideology in individuals and the method of education which directs members to adopt An-Nabhanism without critical inquiry. Indeed, HTI activists themselves prefer to name their form of learning tatgif'(culturing) rather than ta' $/ \mathrm{m}$ (teaching) or tarbiyya (education). What is more, the limiting of references for study to those written only by An-Nabhani and other HT authors indicates that indoctrination is the method of education in HT.

There are three books studied by new recruits before they progress to actual membership: Nižăm al-Isläm, al-Takattul al-Hiðbiy, and Mafähim Hizbut Tabrir. The systematic order of presenting material indicates that HT employs a series of subtle and sophisticated stages of indoctrination for novices: the three basic books serve to equip the minds of novices with HT principal doctrines before receiving further doctrines on more detailed topics such as politics, economy and society in Islam. Interestingly, the first two books do not mention HT on any page; only the third presents HT concepts. The impact of the basic books upon HTI members appears to be strong; I heard many terms and concepts derived from the books voiced in the interviews that I conducted. Therefore, I find it important to give a brief description of the works as the following.

${ }^{25}$ Snook, Concepts of Indoctrination, p. 2.

${ }^{26}$ John Wilson, "Indoctrination and Rationality" in Snook, (ed.), Concepts of Indoctrination, pp. 18-19. 
Firstly, Nizām al-Islām briefly addresses broad and various topics in Islam, such as faith (iman), the Islamic system, Islamic civilisation, Islamic law (shari'a), traditions of the Life of the Prophet (sunna), Islamic ethics (akblä) and so forth. It also contains the draft constitution of the Islamic caliphal state formulated by An-Nabhani. Using theological arguments, it enjoins Muslims to use their thinking (mafähim) based on Islamic faith (iman) and to hold totally to the laws of God. The power of the book lies in its philosophical, theological and historical elaboration for arguing that Islam is the most true and rational ideology (mabda') compared to other ideologies, such as capitalism and socialism.

Secondly, al-Takattul al-Hizbiy, drawing on the ideological competition between Pan-Arabism and Pan-Islamism in the Middle East during the 1950s, explains the weaknesses and failures of movements based on Islam, nationalism and communism in dealing with the umma. These it regards as movements without a correct ideology. The book underlines the significance of having a party rather than a social-spiritual organisation to struggle for Islam. It describes the several stages, with relevant strategies, in which a party can establish an Islamic state, namely from culturing, interaction with the umma, to the taking over of political power with the support of the umma. As well, it notes possible barriers in undertaking this $d a^{\prime} w a$ and practical measures to adopt in the struggle.

Thirdly, Mafahim Hiøbut Tabrir describes the concepts adopted by HT. It urges Muslims to revive Islam's glory by returning to a true understanding of the faith, namely an Islam which has both clear thought (fikra) and method (tariqa). It proposes HT as the only party which struggles for such an Islam, with the aim of re-establishing Islamic life all over the world under the caliphate. Various discussions of the principles of shari'a (usül al-fiqh) and method of da'wa are provided to support HT's struggle. At the end of the book, there is a two page profile of HT.

\section{F. Youth and Susceptibility to HTI Indoctrination}

One of the characteristics shared by transnational Islamist movements active in Indonesia, especially HTI and the Tarbiyah Movement is in terms of their demographics. Most members of the movements belong to the younger generation, particularly university students in the 'secular' campuses of big cities. Moreover, the interaction 
with transnational Islamist ideas mostly takes place on campuses through personal student contact, public discussions and training sessions organised by the LDK. Recruitment and indoctrination, as we have discussed, seem essential to gain adherents among these young students. It is important therefore to address the issue of why the youth are susceptible to global Islamist ideology and indoctrination. I suggest that the explanation lies in the nature of the youth themselves, who are seeking an identity on the one hand and the appeal of HT ideology through indoctrination, which provides a sense of certainty to the youth on the other hand.

\section{Seeking Social Bonds and Relief from Frustration}

Several scholarly works have argued that youth are prone to join mass movements and new religious movements. As HTI members mostly become acquainted with and join the movement during the period of their university studies, it can be estimated that their age in early participation is around 18 to 22 . According to Lois Flaherty, for young adults in their early 20 s, this is the time when they consolidate their identity and seek commitment. ${ }^{27}$ She points out that during this period "many young people are still unsettled, trying to work out their relationship to the world. They are determined to make a difference, through changing themselves or the outside world." ${ }^{28}$ In this context, religious movements are one of the institutions which serve to provide and construct a total identity to young people, through what Castells has called 'the process of individuation and internalization. ${ }^{29}$

With regard to HTI members in Makassar, most come from rural areas in South Sulawesi, or from several other provinces in South Sulawesi, as well as from Eastern Indonesian areas such as Kalimantan, Ambon and Nusa Tenggara. Many young people in Eastern Indonesia have traveled to Makassar in order to gain better education and employment. Being away from their homes, they become urbanised, interacting with the results of rapid development and modernisation and living independently. For some

${ }^{27}$ Lois T. Flaherty, "Youth, Ideology, and Terrorism," in Lois T. Flaherty (ed.), Adolescent Psychiatry (London: Career and Technical Education, 2003), p. 46.

${ }^{28}$ Ibid.

${ }^{29}$ Manuel Castells, The Information Age: Economy, Society and Culture, Vol. II, The Power of Identity (Oxford: Blackwell, 1999), p. 7. 
young people, this condition can create a sense of alienation due to a lack of social ties in the city. In addition, the loosening of traditional religious structures due to the impact of massive globalisation can lead them to feel confused and under siege. By engaging with a religious community like HTI, they can overcome these feelings, establishing new social bonds and enjoying the strong solidarity among members. One activist said:

I am from Ternate, Maluku and feel secure with my membership in HTI. I am the only daughter in my family. My family trusts me to pursue my studies here (in Makassar). I have no family here. Because of the strong 'Islamic brotherhood ties' (ikatan ukbuwah) in HTI, my family believes that I can take care of myself and maintain my right behaviour. Besides, the social interaction (pergaulan) in HTI is also good. ${ }^{30}$

In the HTI community, young people form new and strong social relationships. Brotherhood and sisterhood is not only established among members of one campus but also with those on other campuses, who further widen their networks and friendships. The members often emphasise that what unites them in HTI is belief (aqida) and ideology, regardless of background, nation, ethnic community or occupation. This interaction among members with different backgrounds is enabled when they organise or participate in HTI's various activities in Makassar. The strength of brotherhood and sisterhood can be seen from their way of addressing each other as akhi (brother) for fellow male activists and $u k b t i$ (sister) for fellow female ones. Reducing differences among members, it seems that this new shelter provides a sense of egalitarianism and selfesteem among them as they share the concern to spread $d a$ wa among the umma.

The HTI movement also serves as an outlet for young people to express their frustration. Facing the complexities of life in a big city with various choices of modernity could shake youthful identity. Moreover, the economic crisis since 1998, which has led to the rise of unemployment and economic hardship, might contribute to a greater uncertainty and fear for the future among students and graduates. On the one hand, their families hope for high achievement in their study, yet on the other hand, they have limited sources of funds and facilities. Based on my observations, most HTI members are city dwellers,

\footnotetext{
${ }^{30}$ Interview with Hernawati, Makassar, 29 December 2008.
} 
educated and originating from middle and lower income families. Few HTI members hold good professional positions as lecturers, doctors or government employees (Pegawai Negeri Sipil/ PNS). Rather, many of them are students or unemployed graduates who engage in small business to survive while waiting for an opportunity to apply for government service. In relation to these economic factors, youth who lack direction, satisfactory achievement and meaning in their life are more likely to join HTI. Moreover, the HTI message, which provide ready-made answers to their problems, appeals to such disaffected youths. At an rally organised by women body of Hizbut Tahrir Indonesia, Muslimah HTI, in Makassar, I saw leaflets which stated:

Muslimah HTI calls on Indonesian women to abandon capitalism. In reality, capitalism fails to guarantee the welfare and prosperity of the people and even makes them suffer. This is because capitalism only offers an economic system which is unjust, vulnerable to crisis and identical with new colonialism... Today, Indonesia becomes a milk cow (sapiperah) of America and its allies. Indonesian resources are abundant but many of its people live in poverty. It is not fair for us to maintain the domination of the capitalist ideology in Indonesia. Therefore, Muslimah HTI calls on Indonesian women to struggle for shari' $a$ and the caliphate. With shari' $^{2}$, we can have Islamic ideology, derived from God. It is an Islamic economic system, based on Islamic ideology, which can bring prosperity to the people and make a great, strong and leading country. ${ }^{31}$

The messages of HTI are often framed in revolutionary language which accords with the psychology of the youth, who tend to be rebellious. Moreover, resistance in the form of street demonstrations has become a new trend for university students, following the fall of Soeharto in May 1998 due to the force of student demonstrations. Participating in HTI action, the youth can show themselves to be the representatives of the people against injustice and oppression, raising their self-esteem and confidence. At a glance, the messages in their pamphlets and banners sound like a socialist or leftist movement in terms of their radical rejection of capitalism and imperialism. These common messages, some written in English, state that Muslims and the Indonesian people are victims

${ }^{31}$ Juru Bicara Muslimah HTI, Seruan Muslimah Hizbut Tahrir Indonesia untuk Tinggalkan Kapitalisme, Tegakekan Syariah dan Khilafah menuju Indonesia Besar, Kuat, dan Terdepan (Jakarta: Kantor Juru Bicara Muslimah HTI, 10 December 2008). 
of un-Islamic ideologies implanted by the West in order to colonise the Muslim world. The jargon of liberation and resistance to capitalism and democracy has been raised, such as "Eliminate Capitalism, Revolution for the Caliphate!," "Capitalism will End, the World Relies on Islam!," "Leave Capitalism, Be alert about Democracy!," "Caliphate Yes, Capitalism and Democracy No!," "Save Women from Capitalism and the Trap of Democracy!", and "Save Indonesia with the Shari" $a$ and the Caliphate!."

\section{Seeking Certainty}

When negotiating identity in a confusing world, youth are susceptible to religious doctrines which promise certainty. Youth who lack a background in the traditional Islamic education of the pesantren and those from the science and engineering disciplines are more receptive to HTI indoctrination. In my observations, I found only a few bizbiyyin from the Alauddin State Islamic University (UIN Alauddin) in Makassar, while many more hail from the 'secular' majors of campuses such as UNM, UNHAS and UMI. When looking for HTI activists on the UNM campus to carry out interviews, some students suggested that I look in the Faculty of Natural Science and Mathematics (Matematika dan Ilmu Pengetabuan Alam/MIPA) rather in the Faculty of Arts and Language (Sastra). My interaction with bizbiyyin confirmed that HTI has won more followers from Science and Engineering than from the disciplines of Religious Studies, Social Sciences and Arts. Having a new awareness to return to religion, these students with less Islamic education are more likely to seek 'right' and 'wrong' answers and so are prone to take for granted HTI ideas. Similarly, the students of Science and Engineering tend to employ the 'natural science' paradigm and so accept the doctrines of HTI as something fixed and final. In this respect, to borrow Shamsul's words for describing da'wa-oriented students in Malaysia, "they see 'Islamic knowledge' and 'Islamic theology' in terms of rules, formulae, equations and right and wrong answers." 32 As a result, their understanding of Islam appears legalistic and black and white.

Thus the HTI doctrines, which appear clear, comprehensive and not speculative make sense to young adults who are in search of certainty.

32 Shamsul AB., "Inventing Certainties: the Da'wa Persona in Malaysia," in Wendy James (ed.), The Pursuit of Certainty (London: Routledge, 1995), p. 130. 
It is common that fundamentalist religious movements provide "a unifying philosophy of life" from which the followers can meet personal needs for meaning and coherence in their existence. ${ }^{33}$ In this regard, religious texts form the core from which fundamentalists justify their thought and action. HTI sees the sacred texts of the Qur'an and Hadith through the lens of An-Nabhani's commentary, claiming them to be fixed Islamic teachings which are infallible. An-Nabhani created an Islamic ideology which encompasses various aspects of life such as politics, economics, society, law and ethics, suggesting the comprehensiveness of Islam. Indeed, he authored various works covering myriad aspects which have become the manifesto and doctrinal sources of HT followers. Through An-Nabhani's texts, the HTI members have found what Fealy calls 'a total Islamic identity ${ }^{34}$ and feel no need to look at other religious interpretations. One of the hizbiyyin states:

I have interacted with friends from various Islamic movements in Makassar such as the Salafi and Partai Keadilan Sejahtera/PKS groups. However, I found there is something different in HTI because it places Islam as a comprehensive religion. In HTI, we not only study religion as ritual worship (ibadah ritual) or a spiritual thing, but we see religion as ideology, cultural entity and a basis for developing civilisation. I also feel that HTI is the most serious movement, with its ready concepts to implement Islam comprehensively. Many people only discuss Islam as academic discourse, for example the students at Institut Agama Islam Negeri/IAIN (State Institute for Islamic Studies). They learn Islam theoretically, but only to become lecturers, academicians or writers and then halt their steps there. But as to how to implement Islam, they do not have any concepts of thought or movement. ${ }^{35}$

\section{G. Indoctrinated Narratives: Becoming a Re-born Muslim}

It can be said that amongst transnational Islamist movements, HT develops the most solid cadre building and organised form of mobilisation. Although the members of HTI in Indonesia are small in number in comparison to the large organisations of Nahdlatul

${ }^{33}$ Ralph W. Hood, JR. et.al, The Psychology of Religious Fundamentalism (New York and London: The Guilford Press, 2005), pp. 15-16.

${ }^{34}$ Fealy, "Hizbut Tahrir in Indonesia," pp.151-217.

${ }^{35}$ Interview with Rahim, Makassar, 14 December 2008. 
Ulama/NU, Muhammadiyah and PKS, they show a deep grasp and internalisation of An-Nabhani's thoughts. This is not surprising, since they have studied the three primary books of An-Nabhani under the supervision of their senior member mentors and have exhibited sacrifice and commitment to the movement. In the words of the spokesperson of HTI DPD I Sulsel, "members of HT are guided by a belief in HT ideology and comprehension of its thaqafa (insight)." examine the impact of intensive indoctrination upon bizbiyyin by analysing their common narratives, which indicate that they have become re-born Muslims with a new perspective on life. Since there are various doctrines implanted in the HTI members, I underline the key doctrines which they repeatedly expressed during public rallies and my interviews with them.

\section{Islam as a Total Ideology}

One central doctrine which is adhered to by bizbiyyin is the view of Islam as a total ideology (mabda'). Many members acknowledged that this view was new for them at the first time they joined the halqa but that it grew in its appeal. It is initially introduced from An-Nabhani's first book, Niżăm al-Isläm where An-Nabhani encourages Muslims to adopt Islam as their ideology as it is based on God; he also denounces capitalism and socialism as human-made ideologies. For An-Nabhani, Islamic ideology comprises both fikra (ideas) and tariqa (methods), i.e. that Islam provides a comprehensive set of ideas derived from God and methods to achieve them by following the Prophet's example (sunna). ${ }^{37}$ Given this view, HTI members see Islam as a clear and complete system and Muslims must need to follow the rules. One of the bizbiyyin explained:

Compared to other movements, I see that it is only HT which has clear fikera and tariqa...it is not sufficient to regard Islam merely as religion, it is also ideology. For me, ideology is important because it is the most fundamental idea. If one wants to do something, he must base his or her action on ideology. In any action we have to observe the shari' $a$ - from getting up from sleep, eating, building a family, politics, the economy, social and cultural activities, to the rule of state - everything has to be based on Islam. So, Islam is kaffah (total) and not only confined to ritual. ${ }^{38}$

${ }^{36}$ Interview with Hasanuddin Rasyid, 6 January 2009.

${ }^{37}$ An-Nabhani, Peraturan Hidup dalam Islam, pp. 42-45.

${ }^{38}$ Interview with Farah, Makassar, 23 December 2009. 


\section{The Quest for Shari'a and the Caliphate}

In HT's principles, it is obligatory for Muslims to uphold the

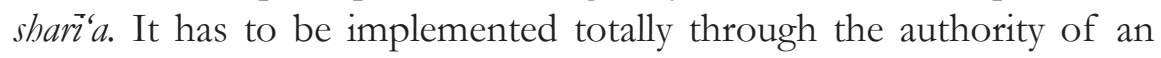
Islamic state (Dawla al-Islamiyya) as experienced by the Prophet and the first Righteous Caliphs. HTI members view Indonesia, and Muslim countries in the Middle East, as not entirely Islamic since they apply kufur (infidel) systems. For the bizbiyyin, the caliphate is the only means to ensure the total implementation of shari $^{-}$a. Based on this logic, they see that establishing a caliphate is also an obligation for Muslims. HTI members I met were well informed and eloquent about the caliphate, not only providing doctrinal and historical arguments for the institution, but they also described in detail the structure of the caliphal state, such as the requirements and methods of appointing a caliph, the function of wali (governors), administrative matters, the form of Islamic courts, and so forth. Hizbiyyin are well-informed about these details because they have grasped them during halqa. I found two HT books which discuss the details of the Islamic state and the caliphate, namely Daulah Islam (The Islamic State) ${ }^{39}$ and Struktur Negara Khalifah (Structure of the Caliphal State)..$^{40}$ Their contents are echoed in the narratives of bizbiyyin. Here is a typical example:

For me, what I understand from HT's struggle is the implementation of shari'a. Yet, we cannot implement shari' $a$ without a state. We offer the benefits of shari'a to be implemented all over the world, but we have no institution which maintains and spreads shari' $a$. Therefore, establishing a caliphate is obligatory. Shari' $a$ implementation cannot be won only in one country, it must have a great power guaranteeing the unity of the umma under one institution, namely the caliphate. It is the caliphate which guards and spreads faith (aqida) and God's shari'a. I believe that some day the caliphate will be established because God and the Prophet have promised us. It is illogical if Muslims themselves do not believe, because even the former US president, George W. Bush, believes that there will be an Islamic institution which will take over the world. I am 100\% sure that the caliphate will be established. We just need more effort and the readiness of the umma. Therefore, $\mathrm{HT}$ is struggling to enlighten the umma,

39 Taqiyuddin An-Nabhani, Daulah Islam (Jakarta: HTI Press, 2007).

${ }^{40}$ Hizbut Tahrir, Ajḥiza al-Dawla al-Kbiläfa, translated into Indonesian, Struktur Negara Khilafah: Pemerintahan dan Administrasi (Jakarta: HTI Press, 2007). 
to prepare them towards the caliphate. ${ }^{41}$

Besides relying on doctrinal sources as formulated by An-Nabhani, the H'TI members often use the historical glory of Islam to argue for the caliphate. They perceive that the condition of Islam in the past, when ruled by a caliph, was much better than the current situation. One activist stated that in the world today one can see human killings and rape taking place every minute. He boasted that during Islam's rule for 13 centuries it could overcome criminality better than today, and this has been acknowledged by some western orientalists. ${ }^{42}$ Another informant told me of the greatness of the Islamic state in Madina where Muslims, Christians and Jews could co-exist in harmony. He also described how science, arts and literature were highly developed in the age of the Abbasid dynasty of Baghdad. It is worth noting that the narratives of hizbiyyin seem uncritical with regard to Islamic history. Like HT literature, what one hears from bizbiyyin narratives is, as Fealy rightly states, "an idealized and romanticized account of how the caliphate operated throughout history." ${ }^{3}$

\section{Resistance to Western Concepts: Against Capitalism and Democracy}

As a part of their indoctrination, the quest for the caliphate and the implementation of shari' a leads hizbiyyin to denounce alien ideologies and 'isms', especially those coming from the West, such as capitalism, socialism, secularism and pluralism. Since socialism has been shown to have failed, the energies of HTI seem more concentrated towards undermining capitalism and democracy, to judge from the voices they raise in the media and their rallies. In any HTI rally and whatever the issue canvassed, one finds voices against capitalism and democracy. What is more, in the HT literature, capitalism and democracy are denounced as the systems of infidels (sistem kufur), the spawn of secularism, full of weaknesses, sources of evil and soft weapons of the West to weaken and colonise the Muslim countries. Rather than self-criticism, HTI members usually blame these Western systems as the source of the problems facing Muslim countries in general. Following HT literature, one of the bizbiyyin narrated:

${ }^{41}$ Interview with Putri, Makassar, 14 January 2009.

${ }^{42}$ Interview with Ansar, Makassar, 10 January.

${ }^{43}$ Fealy, "Hizbut Tahrir Indonesia", p. 163. 
One cause of the decline of Muslims is the domination of the capitalist system with its democracy. In other words, capitalism is established while Islam is abandoned. That is why HT struggles to replace capitalism with an Islamic system. Capitalism only brings decline and bad effects. In reality, this system has failed to bring prosperity to the umma; for example, as we face now, the global financial and economic crisis. In Indonesia, we have seen the presidency has changed overtime, but has never brought any betterment: oil is still scarce, the health service is not optimal and other aspects of people's lives have not been improved. These are all the bad impacts of capitalism and thus they should be replaced with an Islamic system. It is an undeniable fact that, historically, Islam could bring prosperity to the umma. For instance, in the rule of the caliph Umar bin Abdul Azis, there was a time where people refused to be given alms (zakat) because they were all so prosperous. ${ }^{44}$

Emphasising the clash of civilisations, the birbiyyin reject democracy; for them it is a secular concept which is more firmly based on the sovereignty of the people rather than on the rules of God. In their view, within a democratic system any issue whatsoever, whether halal (allowed) or haram (forbidden) might be brought under deliberation, while in Islam only issues which are halal can be discussed. Moreover, they emphasise that matters of Islamic law such as jinayya (criminality) and qisas (punishment) cannot be debated, but have to be strictly implemented. Quoting HTI ideologues, several members argue that democracy is haram from an Islamic perspective. Due to this rejection of democracy, as my informant explained, bizbiyyin in Indonesia do not participate in elections, though this is not publicly announced and there is no stipulation from HTI cenral office in Jakarta regarding the issue.

\section{H. Self-Transformation: Producing a New Identity}

The intensive indoctrination of HTI not only results in shaping the minds of the bizbiyyin as described above, but also leads them to experience transformations in their lives. Viewed from the perspective of the sociology of religion, the change in belief and identity of these youths indicates that they have undergone a total conversion. ${ }^{45}$ Adopting

${ }^{44}$ Interview with Hernawati, Makassar, 29 December 2008.

${ }^{45}$ David A. Snow an Richard Machalek, "The Sociology of Conversion," in Annual Review of Sociology 10 (1984), pp.167-190. 
a complete Islamic identity, many members acknowledged that they have found direction in their lives. As they narrated:

After joining HTI, I personally found a goal in life which I had really wanted. Before knowing Islam and HT, my goal in life was like what people generally want, such as achievement in my studies, getting a good job, getting married, having a family and kids and then entering heaven after death. But after knowing Islam through HTI, I now realise that da'wa is the axis of life (poros hidup). Thus, we have to provide a time for da'wa. Our obligation is not only to perform ritual worship, but also to spread da'wa for the good of the umma. Therefore, although I am busy with my studies I have to manage my time to include da'wa. ${ }^{46}$

After learning Islam in HTI, I felt a change in my views. Previously, like other friends, I just thought about completing my studies, finding a job and then getting married, as well as making my parents happy. That's it. Now, after joining HTI, I do think there was something missing in my life. We should not only think about our individual interests, but we have to pay attention to the umma and struggle for Islam. We not only have to make sure our prayers are good, but also how to think about the problems of the umma, how to enlighten them to support Islamic shari'a so that together we can enjoy prosperity under Islam. ${ }^{47}$

The stories make clear that the biabiyyin have become re-born Muslims. Narratives like these are common in new religious movements. According to Margaret Thaler Singer, members of a new religious movement, when referring to their new social identity, speak of themselves as "transformed, reborn, enlightened, empowered, rebirthed, or cleared". 48 In this respect, their change is reconstructed as demonstrating the emergence of the 'new person'. ${ }^{49}$ 'The bizbiyyin perceive themselves to be agents of God, having a new consciousness and commitment to spread da'wa, which they view as the major activity of life on earth. They have found a high responsibility to care and struggle for the global umma so that they can restore the glory of Islam under the caliphate.

${ }^{46}$ Interview with Putri, Makassar, 14 January 2009.

${ }^{47}$ Interview with Mutiara, Makassar, 25 December 2008.

${ }^{48}$ Margaret Thaler Singer, "The Process of Brainwashing, Psychological Coercion, and Thought Reform", in Lorne L. Dawson (ed.), Cults and New Religious Movements, p. 158.

${ }^{49}$ Ibid. 
Such personal change can also be seen from the appearance and behaviour of the hizbiyyin. While male activists do not adopt any particular change of appearance, the female activists, or akbwat tend to put on a different model of veil and a loose, long flowing robe, which appear more traditional than the general jilbab in Indonesia. They have learned in the religious doctrines of halqa that Islamic clothing consists of jilbab and kbimar. The jilbab is a headscarf combined with a long robe, while khimar is the headscarf combined with separate items of clothing such as a shirt and skirt. This kind of jilbab has become the badge of the religious and social identity of the HT female activists. In terms of behaviour, they keep their actions in accordance with Islamic rules and ethics; for instance, except in the context of gaining education, they avoid interacting personally with males with whom they are potentially allowed to be married (bukan mubrim), or those outside the circle of the family with whom they may interact freely. This is due to the teaching that it is forbidden for a man and a woman to meet and interact in a private place without the presence of others, since it can lead to zina (adultery). In my own experience, I had difficulty in interviewing any female activist unless she was accompanied by a female friend as chaperone. One of my informants even cancelled an interview when her friend could not manage to come and accompany her.

The bizbiyyin do not confine their 'Islamicness' to personal piety, as in other Islamist movements, but following HT doctrines, through real action as they are bound to the global da'wa mission. This may be interpreted as the success of HTI indoctrination which produces such a strong commitment in young Muslims. For them, commitment to HTI is no more than a commitment to Islam itself. The da'wa mission to establish shari' $a$ and the caliphate is embodied deep in the minds and actions of the bizbiyyin. They are not reluctant to spread HTI messages to their family and the public. Some members gave me accounts of how they have struggled to Islamise their family and their social surroundings, receiving both resistance and acceptance in turn. Some of them are also active in writing their opinions in local daily newspapers on various national and local issues, always offering solutions from HT perspectives. While so seeking to Islamise their surroundings, the major activity of the biabiyyin is in seeking recruits, attending and supervising balqa and actively 
organising and participating in HT public activities such as seminars or discussions, demonstrations and rallies.

\section{Conclusion}

This article has shown the relationship between commitment, indoctrination and the vulnerability of youth in being attracted to the HTI movement. It finally concludes that intensive indoctrination through halqa plays a crucial role in molding the minds and behaviour of these young Muslims, which in turn produces an Islamic identity and commitment to HTI. Indoctrination takes the form of traditional Islamic teaching, where a teacher is surrounded by five or six students in the halqa, following the systematic curriculum written by An-Nabhani. Rather than using any critical method, HTI aims to implant HT ideology in young Muslims under the supervision of senior hizbiyyin, so that members can adopt and carry out its teaching correctly. For its certain, uncompromising and revolutionary messages, the HTI ideology is appealing to youth, especially to disaffected university students, who are at the stage of seeking personal empowerment and identity, social bonds and an avenue to vent their frustrations. The bizbiyyin thus emerge as re-born Muslims who adopt a total Islamic ideology and conceive of the da'wa for shari' $a$ and the caliphate as their main undertaking in life. 


\section{BIBLIOGRAPHY}

An-Nabhani, Taqiyuddin, Daulah Islam, Jakarta: HTI Press, 2007.

----, Peraturan Hidup dalam Islam, Jakarta: HTI Press, 2007.

Badruzzaman, “Gerakan Keagamaan 'Hizbut Tahrir' dan Lektur Rujukannya", http://bz69elzam.blogspot.com/2008/07/gerakankeagamaan-hisbut-tahrir-dan.html, accessed 1 April 2009.

Castells, Manuel, The Information Age: Economy, Society and Culture, Vol. II, The Power of Identity, Oxford: Blackwell, 1999.

Fealy, Greg, "Hizbut Tahrir in Indonesia: Seeking a 'Total' Islamic Identity," in Shahram Akbarzadeh and Fethi Mansouri (eds.), Islam and Political Violence: Muslim Diaspora and Radicalism in the West, London and New York: Tauris Academic Studies, 2007.

Flaherty, Lois T, "Youth, Ideology, and Terrorism," in Lois T. Flaherty (ed.), Adolescent Psychiatry, London: Career and Technical Education, 2003.

Hizbut Tahrir Indonesia, Mengenal Hiøbut Tabrir: Partai Politik Islam Ideologis, Pustaka Thariqul Izzah, 2000.

----, Struktur Negara Kbilafah: Pemerintahan dan Administrasi, Jakarta: HTI Press, 2007.

Hood, JR. et.al., The Psychology of Religious Fundamentalism, New York and London: The Guilford Press, 2005.

Juru Bicara Muslimah HTI, Seruan Muslimah Hiøbut Tabrir Indonesia untuke Tinggalkan Kapitalisme, Tegakekan Syariah dan Khilafah menuju Indonesia Besar, Kuat, dan Terdepan, Jakarta: Kantor Juru Bicara Muslimah HTI, 10 December 2008.

Shamsul AB., "Inventing Certainties: the Da'wa Persona in Malaysia," in Wendy James (ed.), The Pursuit of Certainty, London: Routledge, 1995.

Singer, Margaret Thaler, "The Process of Brainwashing, Psychological Coercion, and Thought Reform," in Lorne L. Dawson (ed.), Cults and New Religious Movements: A Reader, USA, UK and Australia: Blackwell Publishing, 2003.

Snook, I. A., Indoctrination and Education, London and Boston: Routledge \& Kegan Paul, 1972. 
---- (ed.), Concepts of Indoctrination: Philosophical Essays, London and Boston: Routledge \& Kegan Paul, 1972.

Snow, David A. and Machalek, Richard, "The Sociology of Conversion," in Annual Review of Sociology 10, 1984.

Sukma, "Hizbut Tahrir Daerah Sulawesi Selatan," Skripsi (Honour thesis) at the Faculty of Social and Political Science, Makassar: University of Hasanuddin, 2008.

Taji-Farouki, Suha, A Fundamental Quest: Hiøb al-Tabrir and the Search for the Islamic Caliphate, London: Grey Seal, 1996.

\section{Interviews}

Ansar, Interview, Makassar, 10 January

Hernawati, Interview, Makassar, 29 December 2008.

Maryam, Interview, Makassar, 9 January 2009.

Mujahidah and Farah, Interview, Makassar, 23 December 2009.

Mutiara, Interview, Makassar, 25 December 2008.

Putri, Interview, Makassar, 14 January 2009.

Rahim, Interview, Makassar, 14 December 2008.

Rahmawati, Interview, Makassar, 9 January 2009.

Rasyid, Hasanuddin, Interview, Makassar, 13 December 2008 and 6 January 2009. 
Syamsul Rijal 